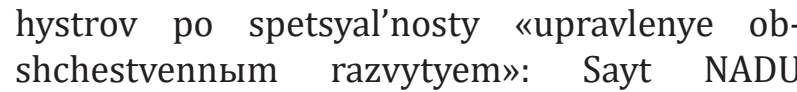
Tsentr dystantsyonnoho obuchenyya; http:// bizztobizz.net/o-zaochno-distantsionnoj-forme-obucheniya-po-programme-podgotovki-magistrov-po-spetsial-nosti-upravlenie-obshestvenny-m-razvitiem-2.html.

5. Potsulko 0. A. Dystantsiyna osvita v Ukrayini / O. A. Potsulko // Naukova skarbnytsya osvity Donechchyny. - 2009. - \#1. - S. 24-28.

6. Stepanenko S. Pro transformatsiyu systemy zaochnoyi osvity v umovakh intehratsiyi v Yevropeys'kyy osvitniy prostir / S. Stepanenko // Vyshcha shkola. - 2007. - \# 2. - S. 31-37.

7. Strel'nikov V. Yu. Tekhnolohiyi dystantsiynoho navchannya u vyshchiy shkoli / V.Yu. Strel'nikov // Novi tekhnolohiyi navchannya: Naukovo-metodychnyy zbirnyk. - K.: Nauk.metod. tsentr vyshchoyi osvity, 2004. - Vyp. 36. S. 41-51.

8. Shevchuk P., Karpuk V. Dystantsiyne navchannya $\mathrm{u}$ formuvanni profesiyno kompetentnykh pratsivnykiv orhaniv derzhavnoyi vlady / P Shevchuk, V. Karpuk // Visnyk Derzhavnoyi Sluzhby Ukrayiny. - 2005. - \# 2. - S. 37-40.

9. Shunevych B.I. Rozvytok osnovnykh komponentiv dlya orhanizatsiyi dystantsiynoho navchannya v Ukrayini / B. I. Shunevych // Problemy osvity: Naukovo-metodychnyy zbirnyk. K.: Nauk.-metod. tsentr vyshchoyi osvity, 2003. Vyp. 33. - S. 45-56.

10. Yatsenko H. Komunikatyvna sutnist' dystantsiynoho navchannya: postanovka problemy / H. Yatsenko // Vyshcha osvita Ukrayiny. 2007. - \# 3. - S. 70-74.

Надійшла 22. 09. 2018.

Бібліографічний опис для цитування:

Гончар С.В. Дистанційна освіта в практиці підвищення професійного рівня муніципальних службовців / С.В. Гончар // Sophia Prima: діалог вічного повернення. - 2019. - № 1. C. 67-74.
УДК 1:37.013.73: 316.32

Н.Є. Доній, д. філос. н., професор

\section{ОСВІТНІЙ ПРОСТІР ЯК ПОСТАЧАЛЬНИК КАПІТАЛУ ЗНАНЬ ДЛЯ СУСПІЛЬСТВА МАЙБУТНЬОГО}

У публікації робиться спроба розкриття сутності освітнього простору як елементу економоцентрованого соціального простору, здатного стати ресурсом для виробництва та накопичення капіталу знань. Вказується, що освітній простір може бути джерелом капіталізації знань, якщо буде існувати, дотримуючись концепції «освіта протягом життя».

Ключові слова: соціальний простір, освітній простір, знання, капітал, освіта протягом життя, цінності.

Доний Н.Е. Образовательное пространство как поставщик капитала знаний для общества будущего.

В публикации предпринимается попытка раскрытия сущности образовательного пространства как элемента экономоцентрированного социального пространства, способного стать ресурсом для производства и накопление капитала знаний. Указывается, что образовательное пространство может способствовать капитализации знаний, если будет функционировать следуя концепции «образование на протяжении жизни».

Ключевые слова: социальное пространство, образовательное пространство, знания, капитал, образование на протяжении жизни, ценности.

Doniy N.E. Educational space as supplier of capital of knowledge for society future

The publication attempts to reveal the essence of the educational space as an element of an economically-centered social space that can become a resource for production and the 
accumulation of knowledge capital. It is stated that the educational space can contribute to the capitalization of knowledge, if it exists, adhering to the concept of «lifelong education».

Key words: social space, educational space, knowledge, capital, «lifelong learning», values.

Актуальність теми дослідження. Сучасний соціальний простір є доволі насиченим різними складовими системами, підсистемами. Ще однією з особливостей сучасного соціального простору $€$ кризовий стан практично усіх згаданих соціальних підсистем, надзвичайно великі соціальні ризики й біфукарційність. За таких умов й попри розчарування в розумі, що притаманне добі пост-Просвітництва, підгрунтям розвитку людства продовжує визнаватися «розумовий запас». Останнє означає, що проблема постачальника знань для формування цього запасу та вплив останнього на результати діяльності суб'єктів стає однією з найактуальніших і визначальна роль в його капіталізації відводиться освітньому простору.

Постановка проблеми. Саме капітал знань виступає не просто мірою людського інноваційного капіталу, але й умовою вітальності та життєстійкості суспільства, а також умовою, від якої залежить забезпечення соціального простору, орієнтованого на креативну економіку, необхідним ресурсом - творчими та активними людьми. Відтак, назрілими стають пошуки того, хто може постачати знання, які кристалізуючись, утворять такий бажаний капітал. У цьому моменті погляди людства повернулися до системи освіти, що все частіше описується як «освітній простір».

Аналіз останніх досліджень і публікацій. Сутнісні характеристики соціального простору простежували відомі філософи, соціологи І. Кант, П. Бурдьє, Е.
Дюркгейм, П.А. Сорокін, Дж. Тернер, М. Хайдеггер та інші. Визначальними для вивчення освітнього простору, як складового його елементу соціального простору, стають 90-ті рр. XX ст. завдяки появі та деталізації поняття «освітній простір» в роботі російських психологів I. Фруміна та Б. Ельконіна «Образовательное пространство как пространство развития». У 1995 р. у збірнику «Новые ценности образования: тезаурус для учителей и школьных психологов» була представлена перша спроба погляду на поняття «освітній простір» крізь призму педагогічної науки та було наведено перше визначення цього поняття як педагогічної категорії. Починаючи з того часу в якості окремого об'єкту наукового інтересу освітній простір розглядався 3 позицій: філософсько-культурологічної (Н. Касярум, В. Конев, Р. Квеско, С. Подмазін, Г. Шевелева); методологічної (С. Алексєев, М. Віленський, Б. Вульфсон, В. Гатальский, О. Леоновой, Г. Серикова, А. Цукер й ін.) педагогічної (В. Гінеціанський, С. Іванова, Д. Коноплянський, Е. Мещерякова, М. Михалик, І. Суріна, Т. Франчук, М. Якушкіна ); психологічної ( $Є$. Бондаревська, В. Серіков, І. Фрумін, Б. Ельконін); проектування освітнього простору (О. Газман, М. Кларін, В.Я. Левін, В.А. Ясвін).

Людський капітал (включаючи його підвид - інтелектуальний) і капітал знань в якості об'єкту досліджень представлено в доробку класиків економічної науки А. Сміта, Г. Беккера, К. Маркса та публікаціях сучасних дослідників Л. Бадалова, У. Буковича, А. Горц, М. Ізотова, Т. Стюарта, К. Нордстрема, Й. Ріддерстраля, Р. Уіллямса та ін.

Виділення недосліджених раніше частин загальної проблеми. Заявлені в назві концепти «освітній простір» і «капітал знань» попри значну кількість публікацій, що пропонують бачення їхньої суті, продовжують залишатися складними, багатовимірними й остаточно нез'я- 


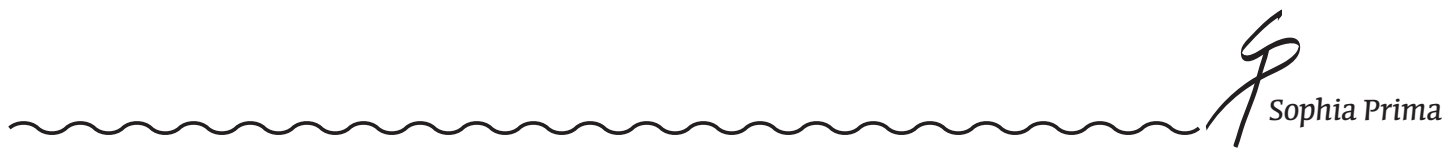

сованими феноменами. Певну ясність в суть вказаних концептів може внести залучення зусиль соціальної філософії, як загальнометодологічної та соціогуманітарної дисципліни.

Постановка завдання. Відповідно, метою даної публікації визначається намагання розкриття сутності освітнього простору не стільки в якості педагогічного феномена, скільки подання його як соціально-економічного феномена та джерела формування капіталу знань, затребуваного новітнім економоцентрованим соціальним простором.

Виклад основного матеріалу. Економічний підхід до людини й її життя не $\epsilon$ чимось новим, проте саме в умовах інформаційного та економоцентрованого суспільства капітал знань визнається провідним ресурсом, володіння й користування яким $\epsilon$ основою діяльності будь-якого соціального суб'єкта (індивіда, організації) та умовою його конкурентоздатності й ефективного функціонування. Відомий французький філософ Жан-Франсуа Ліотар вказав на факт, що «ідея, що знання належить «мозку» чи «духу» суспільства <...> поступово відживає» [1, с. 20-21], бо фактично знання перемістилися в систему виробництва. А це означає вихід на першу позицію нової ідеї - «знання виробляється й буде вироблятися для того, щоб бути проданим, воно споживається й буде споживатися, щоб набути вартості в новій продукції» $[1$, с. 18]. Значимість даного фактора виробництва зростає з кожним днем, адже сучасний світ віддає перевагу інтелектуальній та креативній діяльності суб'єкта. Одразу постають питання: «Хто є виробником знань й хто сприяє формуванню того об'єму, який трактується в якості «капіталу знань?» та «Що ж все ж таки представляє собою «капітал знань?».

Коли мова йде про капітал знань, то найчастіше мається на увазі узагальнення знань, навичок, практичного досві- ду, усього того, що в свою чергу сприяє створенню нового, раніше невідомого знання, яке в майбутньому має забезпечити отримання інтелектуальної ренти i різного роду переваг перед конкурентами. Одним з перших любомудрів, які намагалися створити концепцію знання в тій термінологічній парадигмі, яка використовується в новітніх дослідженнях, був Платон. Він не тільки використовував словосполучення «здобувати знання», «отримувати знання», «знання наростають», «знання убувають», але й вказував, що знання - статичне поняття, яке обіймає усі часи, й зберігається десь, де перебувають душі, які після об'єднання з тілом фактично пригадують те, що колись знали. Та головним для нас в його підході до знання $є$ те, що Платон відзначає, що до сутностей знань належать набуття, володіння й торгівля [Див. 6, с. $258 ; 5$, c. 282], а значить знання $є$ категорією, що добре вписується в економічний дискурс. Зауважимо, такий підхід після Платона був практично забутий до часів Просвітництва й актуалізувався в зв'язку з бурхливим розвитком економіки та переорієнтацією суспільства на товарно-грошові відносини.

В уявленні представників економічної науки кінця XVIII - початку XIX ст.ст. «капітал» був категорією, яку найчастіше використовували для вказівки на фінансові витрати щодо виробництва й стосовно форм неринкової поведінки навіть не розглядався. Перший, хто заговорив про можливість застосування категорії «капітал» стосовно характеристик людини був Джозі Такер, який в 1775 р., описав проблему людських взаємостосунків у фабричній системі Британії того часу. Такер, розглядаючи суперечки що виникали між власниками капіталу і постачальниками робочої сили, відзначив, що кожна сторона намагалася отримати більше вигоди й тому згодом він дійшов висновку: кожна зі сторін вкладає у виробництво більше, 
ніж тільки фізичні або трудові активи, вона вкладає те, що не завжди цінується традиційними компаніями, але те, що $€$ причиною зростання цінності компанії.

До початку XIX ст. ця ідея поширилася не тільки в Британії, але і в континентальній Європі, і в Північній Америці. Вона також справила значний вплив на видатного економіста Адама Сміта, який у своїй праці «The Wealth of Nations» (1776 p.), писав, що поділ праці частково грунтується на ідеї про те, що знання і навички, необхідні для виробничого процесу, можуть бути розподілені серед робітників, залучених до процесу, а не сконцентровані в руках одного робочого, який одноосібно виконує весь процес цілком [7, с. 21-22; 203-204]. 3 поділу праці слідує припущення, що кожному робітникові при цьому потрібно менше знань для роботи, однак організації в цілому необхідний той же обсяг знань, що і раніше. Можна сказати, що Сміт визнає важливість того, що ми зараз називаємо «набуттям знань»: «Освіта простого народу в цивілізаційному й торговому суспільстві, вимагає, мабуть, більшої уваги та сприяння держави, ніж освіта людей знатних і заможних» [7, с. 558]. Але більш важливою думкою стала ідея А. Сміта про знання як капітал. Спочатку Сміт засвідчує, що капіталом є те, від чого людина «очікує отримати дохід» [7, с. 204], а потім, розглядаючи з яких частин складається капітал, в якості складових елементів називає три елементи: те, що призначено для безпосереднього споживання й що не приносить жодної користі (жодного прибутку); основний капітал, який приносить дохід; оборотний капітал.

Основний капітал, згідно теорії Сміта, у свою чергу, поділяється на чотири складові: корисні машини та знаряддя праці: доходні будівлі; покращення землі; набуті й корисні здібності усіх жителів або членів суспільства [7, с. 207-208]. Як бачимо, шотландський економіст фактично в категорію капіталу вводить неринкові елементи й відзначає їхню важливість для накопичення капіталу як окремою людиною, так і суспільством в цілому.

Думка Сміта була продовжена й у певному сенсі розтлумачена Карлом Марксом. За визначенням Маркса: «розвиток основного капіталу $є$ показником того, до якої міри загальне суспільне знання (Wissen, knowledge) перетворюється в безпосередню продуктивну силу, і звідси - $є$ показником того, до якої міри умови самого суспільного життєвого процесу підпорядковані контролю загального інтелекту та перетворені відповідно до нього» [4, с. 127]. Звертає на себе увагу й те, що згідно марксової позиції вчитель, який дає знання (а Маркс навіть вказує про торгівлю знаннями) $\epsilon$ перехідною формою/з'єднучою ланкою в виробництві капіталу [2, с. 100]. Окремо розглядаючи суспільні знання К. Маркс вказує на важливість індивідуальних знань у застосуванні науки: «для аналізу процесу виробництва (традиційних відомостей, спостережень, професійних секретів, отриманих експериментальним шляхом), - це її застосування в якості застосування природничих наук до матеріального процесу виробництва так само лежить на відділенні духовних потенцій цього процесу від знань, відомостей і вміння окремого робітника, як концентрація i розвиток [матеріальних] умов виробництва та їх перетворення на капітал» [3, с. 553].

Ще далі у конкретизації знань як капіталу йде Альфред Маршалл, засновник Кембриджський школи теоретичних основ економіки, який у роботі «The Economics of Industry» (1879 р.) підсумовував все, що було оприлюднено раніше, і в главі «Агенти виробництва» зазначив: «В процесі цивілізаційного розвитку відносна важливість розумової та фізичного праці змінювалася. 3 кожним роком розумова праця ставала все більш важливою, 
а фізична - втрачала свою важливість» [9, c. 9]. Маршалл причиною таких змін називає механізацію праці. Розмірковуючи щодо поділу праці, видатний економіст вказує на негативні наслідки цього процесу, а саме на звуження об'єму навичок і детермінацію більшої спеціалізації та відзначає й позитив - синхронне стимулювання потреби в більшій кількості рівнів майстерності та знань всередині кожної спеціалізації. Розмірковуючи, Маршалл висловив таку думку: «Вже виявлено, що важливість майстерності та інтелекту, необхідних для управління і використання сліпих сил природи, зростає <...> Дійсно, загальна освіта разом зі спеціальною стають 3 кожним роком все більш необхідними для працюючої частини населення» $[9$, с.10]. Як правило здатність до змін і нововведень пов'язана 3 ключовими ланками людського капіталу: з більш високим рівнем освіти, 3 більш широкою кваліфікацією, здатністю перенавчатися, рівнем творчості та інноваційності індивіда. Отже, фактично Маршал засвідчив тенденцію, що працююча людина не може зупинятися виключно на рівні шкільної освіти, вона має постійно вдосконалюватися професійно. Його умовивід не втратив актуальності й в новітніх умовах і навіть збільшив ї̈, адже динамізм, мобільність, гнучкість і високий адаптаційний потенціал на сьогоднішній день $\epsilon$ основними характеристиками соціальної істоти та $є$ явищами, які вимагають постійного відшліфовування системою освіти.

Сучасному соціальному простору вже недостатньо вимагати від людини формальної освіти, тому й постало необхідність включення в освітній процес й інших закладів, що зорієнтовані у своїй діяльності на надання освітніх послуг. Така переорієнтація системи освіти дозволяє людині, в міру виникнення потреби, включатися в будь-який період свого життя в освітній процес. Останнє, в свою чергу, також змусило цю систему самозмінитися, перетворившись на освітній простір.

Освітній простір представляє собою складне багатоаспектне явище, що все частіше пов'язується з визначенням соціального простору та соціального ландшафту. Освітній простір є підпростором (полем) соціального простору, це сукупність історично сформованих складових, основна мета яких - допомога в розвитку і збереженні цілісної особистості та сприяння збереженню особистістю конкурентоздатності й вітальності в умовах соціального простору, який відрізняється небаченим раніше динамізмом і домінування економіки над усіма іншими елементами цього простору.

Трансформація в освітній простір дозволила вести мову про систему безперервної освіти, що залучає формальні та неформальні види навчання та конкурентне середовище освітніх і консалтингових закладів. Доцільність системи безперервної освіти обумовлена вже згаданою спеціалізацією та скороченням «життєвого циклу» знань, навичок і професій. Також високі темпи науково-технічного прогресу в альянсі з економоцентризмом вимагаються регулярного оновлення індивідуальних здібностей, знань, підвищення кваліфікації, професійно перепідготовки кадрів, всього того, що й мали на увазі класики економічної науки, описуючи суть капіталу знань. Враховуючи це й діючи у певному сенсі у власних інтересах освітній простір, який також перелаштовується на виробництво, по-перше, намагається утримати людину в своїх межах, надаючи різні види освітніх послуг, а по-друге, змінює стару концепцію «освіта на все життя» на нову - «освіта протягом життя», чим і сприяє капіталізації знань. Капітал знань, як корисний ресурс, може стати потужною конкурентною перевагою об'єкта, про що й вели мову С. Алберт, К. Бредлі 
капіталізація знань «це перетворення знань і невловимих активів в корисні ресурси, які дають конкурентні переваги індивідуумам, фірмам і націям» [8].

Крім того, освіта протягом життя дозволяє вести мову про відсутність єдиної траєкторії руху в набутті освіти та робити «зупинки», що в свою чергу дозволило освітньому простору доволі вдало варіювати час навчання, форми самопрезентації та інформаційне наповнення. Освітній простір і ті соціальні мережі, які формуються в його рамках, створюють для індивіда бажану ситуацію вибору того, що більше відповідає потребам людини й що відповідає соціальному запиту. Дослідження останніх років демонструють, що система соціально-схвальних ціннісних уявлень набуває тенденцію прагматичних орієнтацій. Індивіди, орієнтуючись на матеріальне благополуччя і високий заробіток, прагнуть не тільки достатку як такого, скільки затребуваної професії, гарної та цікавої роботи. Й освітній простір, підлаштовуючись до таких вимог, намагається надати необхідні людині курси, програми, тренінги.

Відзначимо, таке намагання має як позитивні моменти, так і негативні. Зупинимося на останніх. До негативних можна віднести комерціалізацію освітнього простору. Так, зростання тенденції комерціалізації створює істотні обмеження для «слабких» соціальних груп й тому здається гарна ідея «освіти протягом життя» може бути поставлена під загрозу, адже щоб здобувати та накопичувати актуальні знання людині необхідно вкладати кошти, яких вона або не має, або не готова витрачати на капіталізацію знань. Це в свою чергу ставить дві задачі перед соціальним простором: 1) щодо пропагування необхідності здобуття та удосконалення освіти людиною протягом життя та 2) щодо залучення в освітній простір і процес виробничого сектору, який може приймати участь в якості кредиторів для тих, хто бажає вчитися й хто готовий потім віддавати власний капітал знань своєму кредиторові.

Висновки та перспективи подальших досліджень. Таким чином, короткий аналіз теоретичної бази філософсько-економічного характеру дозволяє зазначити, що освітній простір як феномен виник на запит соціального простору й був необхідний як джерело постачання знань, що накопичуючись можуть стати таким затребуваним новітнім економоцентрованим соціальним простором капіталом.

\section{Література}

1. Лиотар Ж.-Ф. Состояние постмодерна / Ж.-Ф. Лиотар ; пер. с франц. Н.А. Шматко. - М. : Ин-т экспериментальной социологии; СПб. : Изд-во «Алетейя», 1998. - 160 с.

2. Маркс К. [Капитал] Книга первая. Глава шестая. Результаты непосредственного процесса производства / К. Маркс // Маркс К., Энгельс Ф. Сочинения. Изд.2-е. - М. Изд-во политической литературы, 1974. - Т.49. - С.3136.

3. Маркс К. К критике политической экономии [Экономические рукописи 1861-1863 годов] / К. Маркс // Маркс К., Энгельс Ф. Сочинения. Изд.2-е. - М. Изд-во политической литературы, 1973. - Т.47. - 677 с.

4. Маркс К. Экономические рукописи 18571859 годов (Первоначальный вариант «Капитала») Часть вторая / К. Маркс // Маркс К., Энгельс Ф. Сочинения. Изд.2-е. - М. Изд-во политической литературы, 1969. - Т.46. - Ч. II. -244 c.

5. Платон Софист / Платон // Платон Собрание сочинений в 4-х т. / Общ.ред. А.Ф. Лосева, Р.Ф. Асмуса, А.А. Тахо-Годи; примеч. А.Ф. Лосева и А.А. Тахо-Годи ; пер.с древнегреч. М. : Мысль, 1993. - - -Т.2. - С.275-345.

6. Платон Теэтет / Платон // Платон Собрание сочинений в 4-х т. / Общ.ред. А.Ф. Лосева, Р.Ф. Асмуса, А.А. Тахо-Годи; примеч. А.Ф. Лосева и А.А. Тахо-Годи; пер.с древнегреч. - М. : Мысль, 1993. - . - Т.2. - С.192-274.

7. Смит А. Исследование о природе и причинах багатства народов / Адам Смит ; вступит.статья и коммент. к.экон.н. В.С. Афанасьева. - М. : Соцэкгиз, 1962. - 684 с. 


\section{№1 2019}

8. Albert S. Intellectual Capital as the Foundation for New Conditions relating to Organizations and Management Practices / S. Albert, K. Bradley. - Milton Keynes : Open University Business School, 1996. - (Working Paper Series; № 15).

9. Marshall A., Marshall M.P. The Economics of Industry / Alfred Marshall, Mary Paley Marshall. - London : Publisher Macmillan and Co., 1879. $306 \mathrm{p}$.

\section{References}

1. Lyotar Zh.-F. Sostoyanye postmoderna / Zh.-F. Lyotar ; per. s frants. N.A. Shmatko. - M. : Yn-t эksperymental'noy sotsyolohyy; SPb. : Yzdvo «Aleteyya», 1998. - 160 s.

2. Marks K. [Kapytal] Knyha pervaya. Hlava shestaya. Rezul'tatы neposredstvennoho protsessa proyzvodstva / K. Marks // Marks K., Эnhel's F. Sochynenyya. Yzd.2-e. - M. Yzd-vo polytycheskoy lyteraturd, 1974. - T.49. - S.3136.

3. Marks K. K krytyke polytycheskoy эkonomyy [Эkonomycheskye rukopysy 1861-1863 hodov] / K. Marks // Marks K., Эnhel's F. Sochynenyya. Yzd.2-e. - M. Yzd-vo polytycheskoy lyteraturb, 1973. - T.47. $-677 \mathrm{~s}$.

4. Marks K. Эkonomycheskye rukopysy $1857-$ 1859 hodov (Pervonachal'nыy varyant «Kapytala») Chast' vtoraya / K. Marks // Marks K., Эnhel's F. Sochynenyya. Yzd.2-e. - M. Yzd-vo polytycheskoy lyteraturd, 1969. - T.46. - Ch. II. $244 \mathrm{~s}$.

5. Platon Sofyst / Platon // Platon Sobranye sochynenyy v 4-kh t. / Obshch.red. A.F. Loseva, R.F. Asmusa, A.A. Takho-Hody; prymech. A.F. Loseva y A.A. Takho-Hody ; per.s drevnehrech. - M. : Musl', 1993. - . -T.2. - S.275-345.

6. Platon Teэtet / Platon // Platon Sobranye sochynenyy v 4-kh t. / Obshch.red. A.F. Loseva, R.F. Asmusa, A.A. Takho-Hody; prymech. A.F. Loseva y A.A. Takho-Hody; per.s drevnehrech. - M. : Musl', 1993. - . - T.2. - S.192-274.

7. Smyt A. Yssledovanye o pryrode y prychynakh bahat.stva narodov / Adam Smyt ; vstupyt. stat'ya y komment. k.эkon.n. V.S. Afanas'eva. - M. : Sotsэk·hyz, 1962. - $684 \mathrm{~s}$.

8. Albert S. Intellectual Capital as the Foundation for New Conditions relating to Organizations and Management Practices / S. Albert, K. Brad- ley. - Milton Keynes : Open University Business School, 1996. - (Working Paper Series; \# 15).

9. Marshall A., Marshall M.P. The Economics of Industry / Alfred Marshall, Mary Paley Marshall. - London : Publisher Macmillan and So., 1879. $306 \mathrm{p}$.

Надійшла 20.09. 2018

\section{Бібліографічний опис для цитування:}

Доній Н.Є. Освітній простір як постачальник капіталу знань для суспільства майбутнього / Н.Є. Доній // Sophia Prima: діалог вічного повернення. - 2019. - № 1. - С. 74-80. 